\title{
A Spatial Analysis of Subgrade Density Value of Cisumdawu Hihgway (KM 10+700 - 12+000)
}

\author{
Ihwan Fauzi', Eri Susanto \\ 1 ihwan.fauzi@pusjatan.pu.go.id \\ 1, 2 Puslitbang Jalan dan Jembatan, Kementerian PUPR
}

\author{
Submitted \\ January 6, 2019
}

\author{
Revised \\ June 24, 2019 \\ http://dx.doi.org/10.17509/jpis.v28i1.14714 \\ Accepted \\ June 24, 2019
}

\begin{abstract}
Uniformity of subgrade density value is very necessary, including in Cisumdawu highway. Spatial analysis with geostatistical computation was applied to predict and map subgrade density value. Geostatistical method used was kriging method based on semivariogram model. The data collected were a sandcone test from 2 zones of dry density value at last layer of compaction. Results of spatial measurements showed that existing values have spatial correlation with diversity influenced by distance and type of distribution, also direction of data distribution from subsgrade density. Zone 1 reached level of compatibility of 99.5\% and Zone 2 of 99.4\%. Mapping value of subgrade density was influenced by normal data distribution, distance between samples and spread pattern. Selection of semivariogram model showed standard deviation value in zone 1 of 0.0025 and zone 2 of 0.004 , it indicates accuracy could meet confidence level of $95 \%$. This result was expected to provide accurate evaluation of subgrade compaction work.
\end{abstract}

Keywords: Subgrade density, spatial variability, geostatistic, kriging

\begin{abstract}
ABSTRAK
Keseragaman nilai kepadatan tanah dasar sangat diperlukan dalam memenuhi kriteria perkerasan jalan, khususnya jalan bebas hambatan Cisumdawu. Analisis spasial dengan pendekatan geostatistika digunakan untuk memprediksi dan memetakan nilai kepadatan tanah dasar. Metode geostatistika yang digunakan adalah metode kriging berdasarkan model semivariogram. Data yang digunakan adalah data hasil uji sandcone pada 2 zona nilai kepadatan kering pada lapisan terakhir pemadatan. Hasil analisis spasial menunjukkan bahwa nilai kepadatan memiliki korelasi spasial dengan keragaman yang dipengaruhi jarak dan tipe sebaran, serta arah sebaran data kepadatan tanah dasar. Zona 1 mencapai tingkat kecocokan sebesar 99,5\% dan zona 2 sebesar 99,4\%. Pemetaan nilai kepadatan tanah dasar dipengaruhi oleh data yang terdistribusi normal, jarak antar sampel dan pola penyebarannya. Pemilihan model semivariogram memberikan nilai standar deviasi pada zona 1 sebesar 0,0025 dan zona 2 sebesar 0,004, hal ini menunjukkan bahwa ketelitian yang memenuhi tingkat kepercayaan 95\%. Hasil analisis ini diharapkan dapat memberikan gambaran evaluasi pekerjaan pemadatan tanah dasar secara akurat.
\end{abstract}

Kata kunci: kepadatan tanah dasar, variabilitas spasial, geostatistik, kriging

\section{PENDAHULUAN}

The weight of a road is held by the subgrade level of the soil; thus, the soil will have a bigger chance to get damaged when it is weak. It is then necessary to meet the density criteria of the soil.
In relation to the value uniformity of soil, people have been using statistical computation; however, geospatical technology gives easier access to assess the uniformity level of the subgrade. Thus, the selection of geospatial technology is a foundational 
reason to have efficient measurement of the subgrade density in the road construction [1].

Subgrade is an important factor in the pavement system so that there needs to be Quality Control (QC) and Quality Assurance (QA). In this study, sandcone test was used for the $\mathrm{QC}$ and QA. Some of the problems rising in the pavement system are 1) limited sample spots which do not represent the whole construction area; and 2) the possibility of the weak soil undientification which leads to bad long-term performance, higher cost, and shorter life cycle [2].

Geostatistical method is used to acquire information on the measurement data of a certain spatial location so that the data distribution trends and the uniformity level of the subgrade density are presented [3]. The value measurement of the subgrade density was done based on the limited number of samples. The sampling carried out in this study several spots in between every 200 meter according to SNI 2828-2011, it has been found that statistically, the condition was not ideal for the density. Thus, a more representative sampling technique is needed because the more representative the sample of a populcation is, the more the chance of generaliability rises.

The use of the soil density value on soil compaction becomes a quite serious issue when it is used to describe the uniformity of subgrade compaction [4]. Whereas, it is known that in a certain area, the value of the subgrade compaction is determined spatial inuniformity. The term "geostatistics" is used to analyze space-based data using such statistical data as mean, deviation standard, and correlational distance among samples [5]. The development of geostatistics-based technology has been conuducted in several studies. One of which has been done in Oklahome, the US, on the use of Intelligent Compation Analyzer (ICA) device to evaluate the subgrade module when investigating the compaction process [6]. Geostatistical approach used in Intelligent Compaction aims to reach uniformity of the compaction of the pavement layer in an attempt to improve the quality of construction, pavement performance, and construction cost [7].

Geostatistical analysis using semivariogram model is able to describe the characteristics and measure the inuniformity of the soil embankment compaction. This is an important element in compaction construction [8]. Geostatistics is also able to visualize the value distribution of the subgrade density as the result of soil compaction. This study is expected to be able to determine the distance sampling patterns of the subgrade density so that the uniformity of the soil compaction can be evaluated. The soil density testing can use sand cones according to the national standard of SNI 03-28281992 (compaction testing method using a sand cone as a tool). Soil compaction results in the improvement of soil density, bulk density, volume of water, carrying capacity in the total porosity decrease, air compressing of the soil, water infiltration line, and the conductivity of saturated hyrolics [9].

As science and technology develops, geostatistics is used more widely, particularly in relation to data influenced by spatial inuniformity. Two set of data with equal mean, deviation standard, and other elements possibly have different spatial representation [3]. In this context, geostatistics focuses on spatial data seti with semivariogram as a tool to describe spatial relation. 
Semivariogram is defined as one and a half of the average squared difference between a certain value and distance. If this value is calculated several times for difference distance, the experimental semivariogram plot $y(h)$ is calculated as follows [10]:

$\gamma(h)=\frac{1}{2 n(h)} \sum_{i=1}^{n(h)}\left|z\left(x_{i}+h\right)-z\left(x_{i}\right)\right|^{2}$

(1)

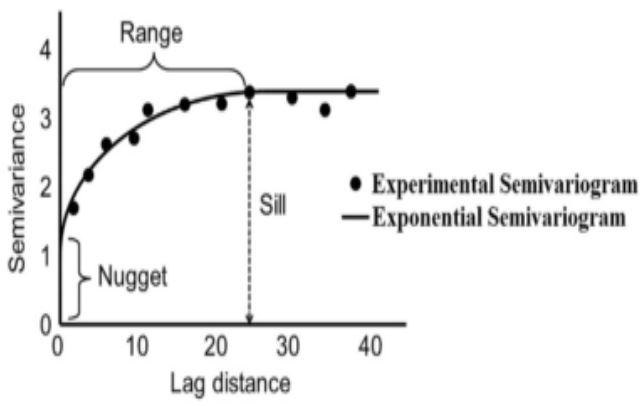

Sourcer: Hu et al. [10]

Figure 1. Typical Semivariogram Sample

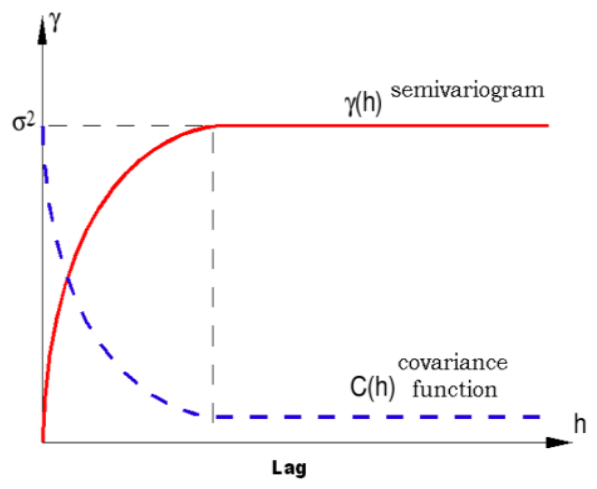

Source: Laksana [11]

Figure 2. Plot of Covariance Function with Semivariogram

The purpose of the study is to mao the value of subgrade density on the development of Cisumdawu highway (KM 10+700-12+000).

\section{RESEARCH METHOD}

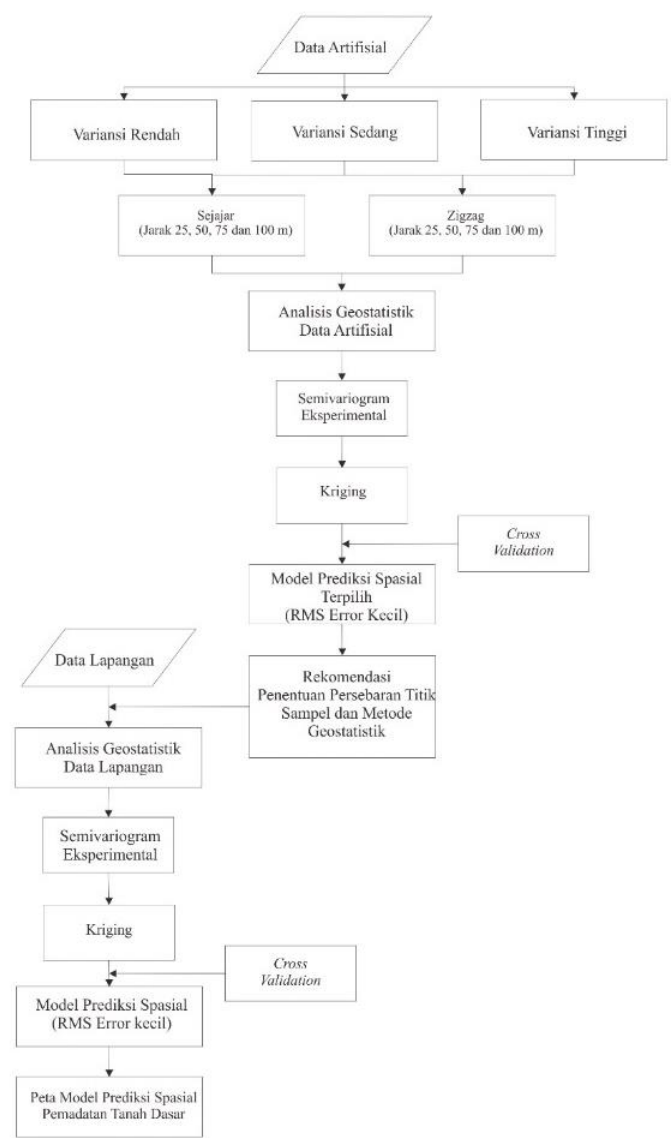

Figure 3. Diagram of the development of subgrade density level uniformity model

The model development consits of several phases. The first phase involves analysis to determine the appropriate model based on the data tendency. The model developed should not only depend on the characteristics of data, but also other factors. In addition to data pre-processing, there needs to be spatial correlation analysis as well. Some methods such as kriging requires the data analysis process using semivariogram and covariance functions. 


\section{RESULTS AND DISCUSSION}

Artificial data are used to acquire strategic recommendation on data analysis.

Table 1. Results of the Soil Density Measurement using Sandcone

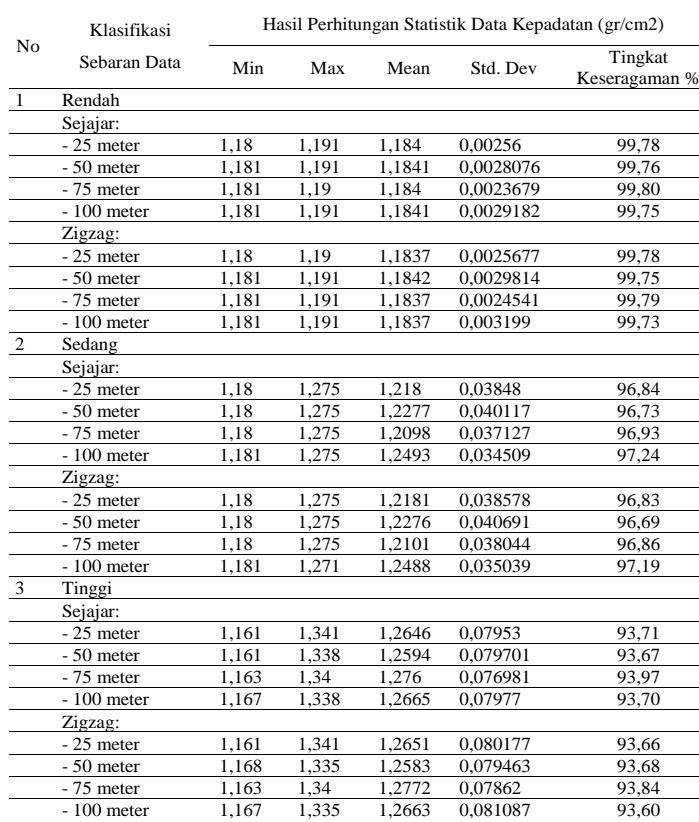

Table 2. Errors on the predictive results on the distance and type of value distribution of subgrade density

\begin{tabular}{|c|c|c|c|c|c|c|c|}
\hline \multirow[b]{2}{*}{ No } & \multirow[b]{2}{*}{$\begin{array}{c}\text { Klasifikasi } \\
\text { Sebaran Data }\end{array}$} & \multicolumn{6}{|c|}{ Nilai Kesalahan } \\
\hline & & $\begin{array}{l}\text { Jumlah } \\
\text { Sampel }\end{array}$ & Mean Error & RMS Error & $\begin{array}{c}\text { Mean } \\
\text { Standar } \\
\text { Error }\end{array}$ & RMS Standar & $\begin{array}{c}\text { Rata-rata } \\
\text { Kesalahan } \\
\text { Standar }\end{array}$ \\
\hline \multicolumn{8}{|c|}{$\begin{array}{c}\text { Variansi Rendah } \\
(0.011<\gamma<0.086) \\
\end{array}$} \\
\hline \multicolumn{8}{|c|}{ Sejajar: } \\
\hline & -25 meter & 128 & $-2,15 \mathrm{E}-06$ & 0,000149 & $-0,0066$ & 1,0310 & 0,000144 \\
\hline & -50 meter & 63 & $7,478 \mathrm{E}-07$ & 0,00023 & 0,00135 & 0,8848 & 0,000276 \\
\hline & -75 meter & 44 & 0,0000022 & 0,000247 & 0,00593 & 1,047 & 0,000235 \\
\hline & -100 meter & 32 & $-0,000013$ & 0,000256 & $-0,02044$ & 0,9556 & 0,000263 \\
\hline \multicolumn{8}{|c|}{ Zigzag: } \\
\hline & -25 meter & 66 & $3,6804 \mathrm{E}-06$ & 0,000305 & 0,00715 & 0,91581 & 0,00036 \\
\hline & -50 meter & 31 & 0,00029 & 0,00056 & 0,038 & 1,033 & 0,00054 \\
\hline & -75 meter & 22 & $2,9405 \mathrm{E}-06$ & 0,000132 & 0,0077 & 0,8976 & 0,00019 \\
\hline & -100 meter & 16 & 0,000016 & 0,00024 & 0,023 & 0,6060 & 0,00041 \\
\hline \multicolumn{8}{|c|}{$\begin{array}{l}\text { Variansi Sedang } \\
(0.086<\gamma<0.161) \\
\end{array}$} \\
\hline \multicolumn{8}{|c|}{ Sejajar: } \\
\hline & -25 meter & 72 & $-0,0000421$ & 0,0052 & $-0,00098$ & 0,71433 & 0,0071 \\
\hline & -50 meter & 36 & $-0,0002461$ & 0,0043 & $-0,04916$ & 1,60090 & 0,0027 \\
\hline & -75 meter & 24 & 0,0001098 & 0,0041 & 0,02135 & 1,01074 & 0,0040 \\
\hline & -100 meter & 20 & $-0,0000407$ & 0,0046 & $-0,00168$ & 1,25620 & 0,0037 \\
\hline \multicolumn{8}{|c|}{ Zigzag: } \\
\hline & -25 meter & 36 & $-0,0019707$ & 0,0141 & $-0,04032$ & 0,49101 & 0,0256 \\
\hline & -50 meter & 18 & $-0,0031616$ & 0,0139 & $-0,05873$ & 0,48453 & 0,0278 \\
\hline & -75 meter & 12 & $-0,0001923$ & 0,0042 & $-0,01691$ & 0,70349 & 0,0061 \\
\hline & -100 meter & 10 & 0,0004435 & 0,0032 & 0,03693 & 0,39805 & 0,0079 \\
\hline y & $\begin{array}{l}\text { Variansi Tinggi } \\
(\gamma \geq 0.086)\end{array}$ & & & & & & \\
\hline \multicolumn{8}{|c|}{$\begin{array}{l}(\gamma \geq 0.086) \\
\text { Sejajar: }\end{array}$} \\
\hline & -25 meter & 68 & 0,0001550 & 0,0087 & 0,01093 & 1,11750 & 0,0080 \\
\hline & -50 meter & 36 & $-0,0000437$ & 0,0061 & $-0,00616$ & 0,75694 & 0,0081 \\
\hline & -75 meter & 24 & 0,0004242 & 0,0061 & 0,04128 & 1,19845 & 0,0052 \\
\hline & -100 meter & 20 & 0,0001671 & 0,0048 & 0,01687 & 0,97084 & 0,0049 \\
\hline \multicolumn{8}{|c|}{ Zigzag: } \\
\hline & -25 meter & 34 & 0,0009774 & 0,0695 & 0,00522 & 0,88072 & 0,0782 \\
\hline & -50 meter & 18 & $-0,0008758$ & 0,0112 & $-0,01750$ & 0,60560 & 0,0208 \\
\hline & -75 meter & 12 & $-0,0002039$ & 0,0083 & $-0,00607$ & 0,56446 & 0,0183 \\
\hline & -100 meter & 10 & 0,0001985 & 0,0083 & 0,01830 & 0,45580 & 0,0195 \\
\hline
\end{tabular}

The predictive model made from the different distribution type gives the average of error in the process of cross validation.

Perbandingan Rata-rata Kesalahan untuk Setiap Perbedaan Jarak

0.1200

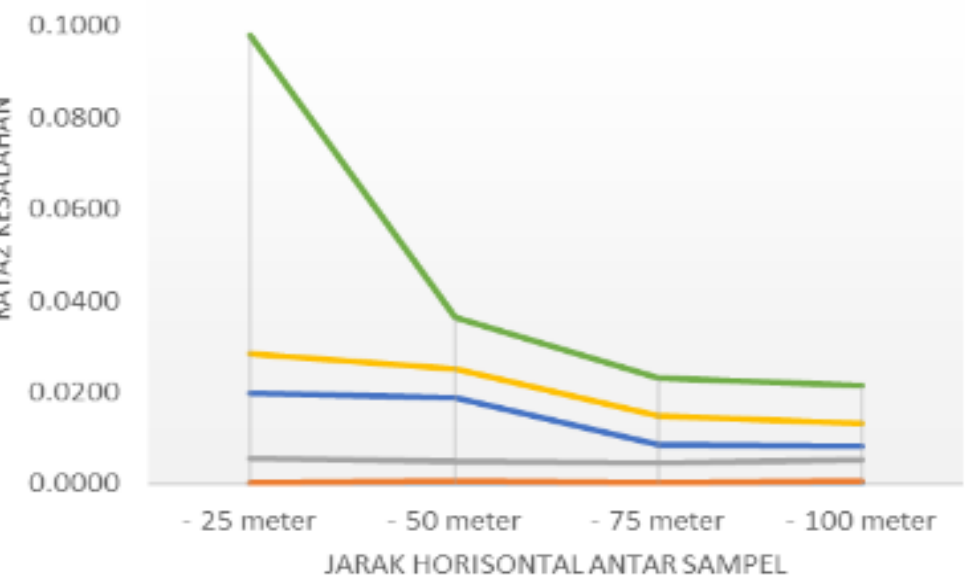

—Zigzag Variansi Tinggi

Sejajar Variansi Tinggi

_Zigzag Variansi Sedang

- Sejajar Variansi Sedang

- Zigzag Variansi Rendah

— Sejajar Variansi Rendah

JARAK HORISONTAL.ANTAR SAMPEL

Figure 4. Comparison of the average of standard errors on every distance difference 


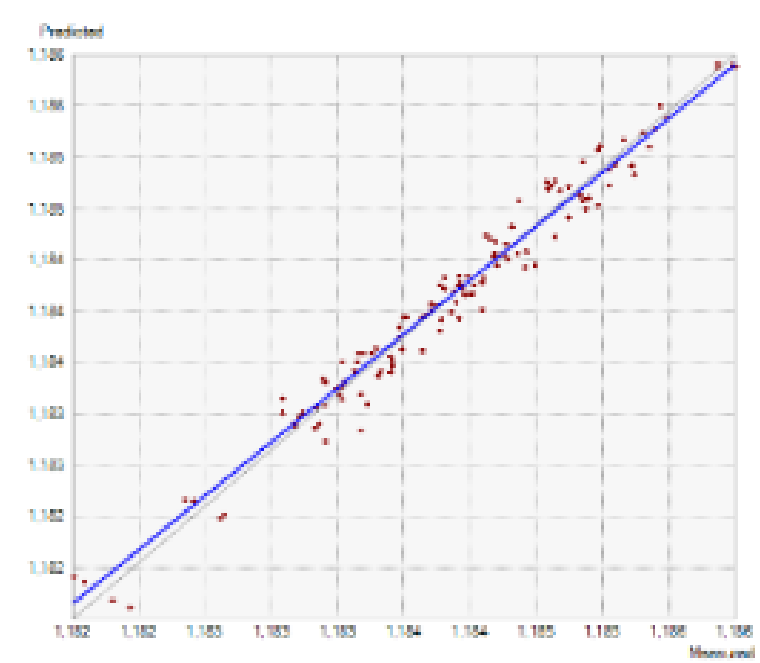

(a)

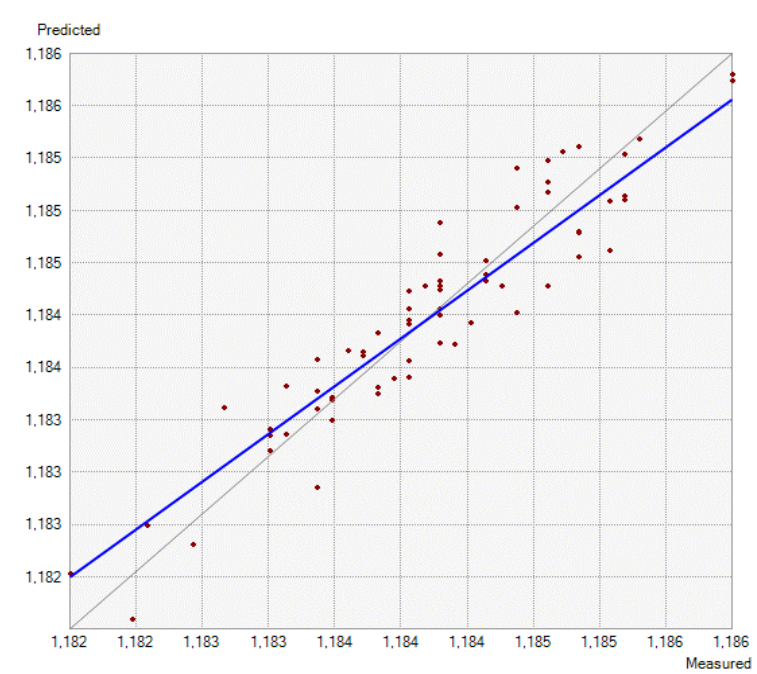

(b)

Figure 5. Comparison of cross validation results on low variance (a) parallel distribution type; and (b) zigzag type

Figure 5 shows the results of cross validation comparison of the soil density with low variance that the parallel type with 25 meter sample space gives the value of

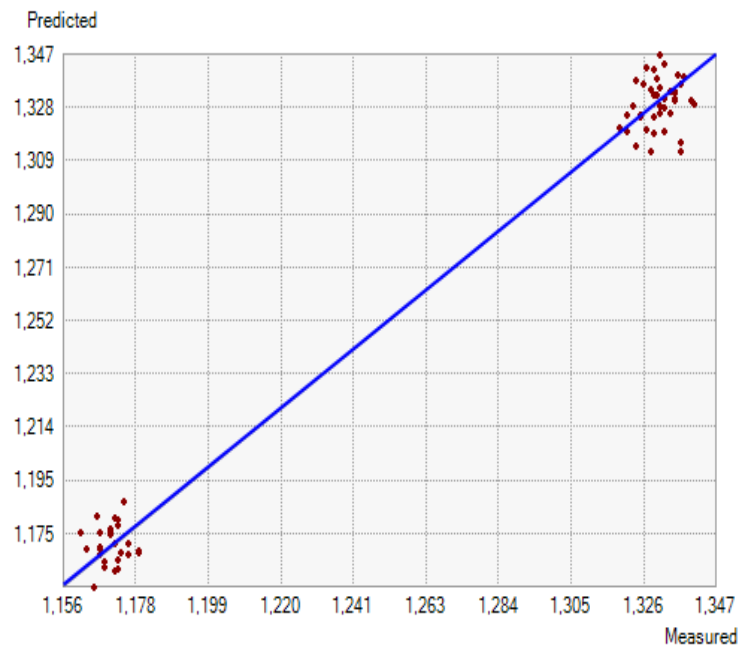

(a) predictive line coinciding with the predictive equation line and results of the measuremen.

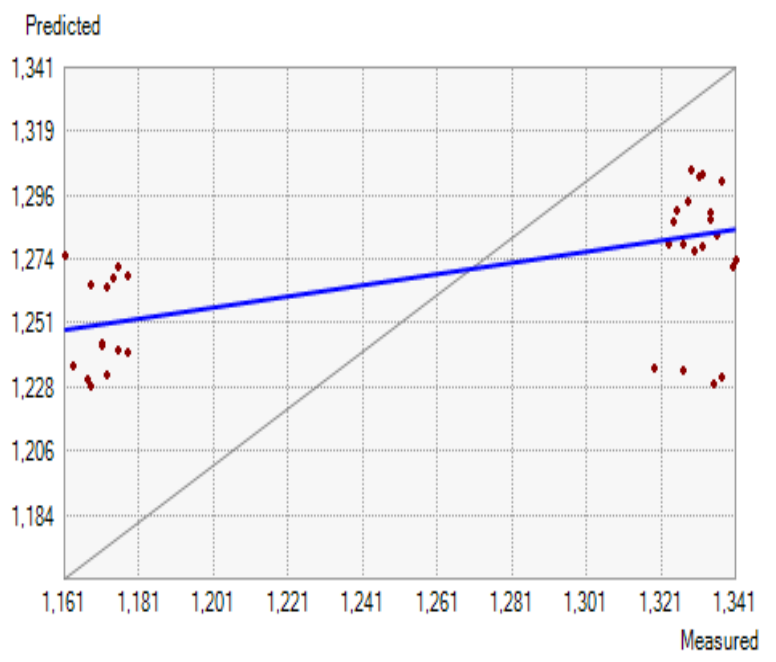

(b)

Figure 6. Results of cross validation on high variance (a) parallel type; and (b) zigzag type 
The distribution of the subgrade density value with a parallel type an high variance gives the results of cross validation which have more uniformity than those in zigzag type in frour different distances. The sampling selection in 25 meter with zigzag pattern shows inconsistency between the predictive results and the real results. Using a geostatistical method as the predictive model, a Gaussian semivariogram model was created. The range value on the same lag is obtained from several trial models of semivariogram (stable, sphrerical, exponential, and Gaussian).

Table 3. Results of geostatistical model on the value of subgrade density and relative compaction ( $R C$ )

\begin{tabular}{rlrr}
\hline No & Results & \multicolumn{1}{c}{ Zone 1} & \multicolumn{1}{c}{ Zone 2} \\
\hline 1 & $\begin{array}{l}\text { Number of } \\
\text { samples }\end{array}$ & 128 & 80 \\
2 & $\begin{array}{l}\text { Mean data } \\
\left(\mathrm{gr} / \mathrm{cm}^{3}\right)\end{array}$ & 11,845 & 1,332 \\
3 & $\begin{array}{l}\text { Deviation } \\
\text { standard }\end{array}$ & 0,003 & 0,005 \\
\hline
\end{tabular}

\begin{tabular}{|c|c|c|c|}
\hline \multicolumn{2}{|c|}{ Semivariogram } & \multirow[b]{2}{*}{135,667} & \multirow[b]{2}{*}{319,8} \\
\hline 1 & Range (meter) & & \\
\hline 2 & Partial Sill & $1,63 \mathrm{E}-02$ & $9,72 \mathrm{E}-02$ \\
\hline 3 & Nugget & $5,26 e-006$ & 2.06E-01 \\
\hline \multicolumn{2}{|c|}{ Error Prediction } & & \\
\hline 1 & RMS & 0,0025 & 0,004 \\
\hline 2 & $\begin{array}{l}\text { RMS } \\
\text { Standardized }\end{array}$ & 0,995 & 0,994 \\
\hline
\end{tabular}

Table 3 infers that the maximum distance of the sampling tehcnique lies on the zones with various values. The number of samples are in line with the samples needed. The value of soil density in zone 1 is lower than that in zone 2 . The semivariogram model proves that the highest range is in zone 2 (336 meters), whilethe maximum distance in zone 1 is 135 meters. The predictive moel in zone 1 has $99.5 \%$ of the matching value and zone 2 is $99.4 \%$. It has also been found that zone 1 has smaller error value compared with that of zone 2.

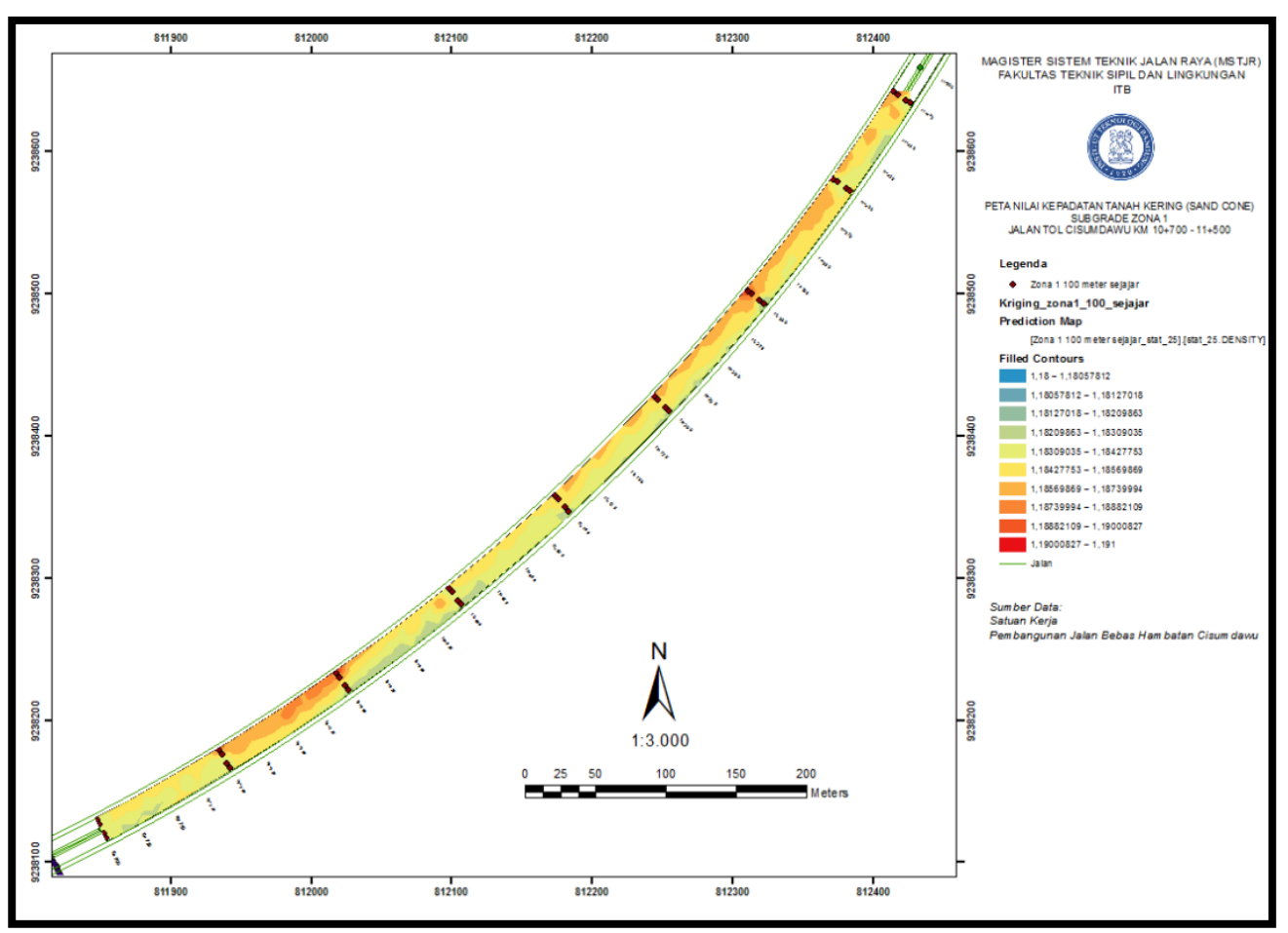

Figure 7. The map of data prediction in zone 1 with parallel type and 100 meter distance 
The map shows the value distribution of the subgrade density in zone 1 ( $\mathrm{KM}$ $10+700-11+500)$. The high value of the densidy lies on the left lane at KM
$10=800$ until $K M 10=900$. Zone 2 shows significance decrease started from KM $11+700$ to $K M 12+000$.

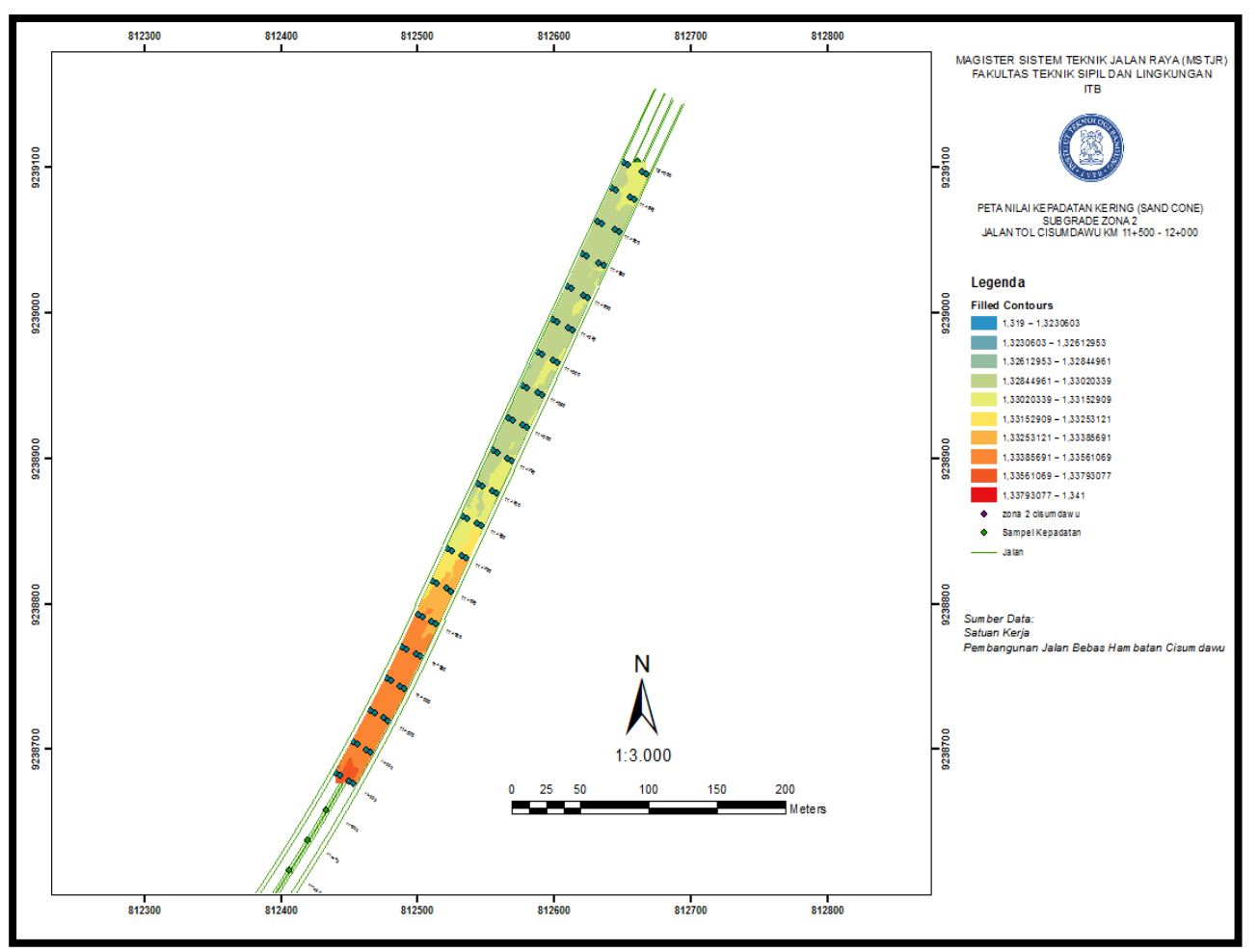

Figure 8. Map of the data prediction model zone 2 with parallel type and 25 meter distance

\section{CONCLUSION}

The mapping of the subgrade density value is influenced by data normally distrbuted, distance among samples and the distribution patterns. The selection of semivariogram model gives the deviation standard value on zone 1 as much as 0.0025 and on zone two as much as 0.004 at the level of signifiance at $95 \%$.

\section{RECOMMENDATION}

Further studies are expected to use $C B R$ data in determining the carrying capacity of the subgrade. The distance is also needed to be increased to 300 meterse.

\section{ACKNOWLEDGMENT}

Authors thank the Ministry of Public Works and Housing of Republic of Indonesia for a scholarship program namely BPSDM, the center of research and development of roads and bridges, the work unit of Cisumdawu highway development project, faculty of civil and environmental engineering, Institut Teknologi Bandung (ITB), Indonesia, master of road system and techniques, ITB, LIPI, and Dr. Maria Margaretha Suliyanti, MT as the promotor.

\section{REFERENCES}

[1] S. Nosov, V. Kuzmichev, S. Repin, and S. Maksimov, "Methodology of Ensuring Road Traffic Safety With Respect to Road-Building 
Materials Compaction Efficiency Factor," Transp. Res. Procedia, vol. 20, no. September 2016, pp. 450454, 2017.

[2] Q. Xu and G. K. Chang, "Evaluation of intelligent compaction for asphalt materials," Autom. Constr., vol. 30, pp. 104-112, 2013.

[3] G. Dondi, C. Sangiorgi, and C. Lantieri, "Applying Geostatistics to Continuous Compaction Control of Construction and Demolition Materials for Road Embankments," J. Geotech. Geoenvironmental Eng., vol. 140, no. 3, p. $06013005,2014$.

[4] S. Budhi, "Aplikasi statistika dalam menentukan nilai karakteristik tanah: sebuah studi pustaka," Indones. J. Geosci., vol. 3, no. 2, pp. 89-93, 2008.

[5] R. J. Barnes, "N11 Geostatistics for Subgrade," Minnesota, 1993.

[6] M. Barman, M. Nazari, S. Asif, and I. Sesh, "Quality control of subgrade soil using intelligent compaction," Innov. Infrastruct. Solut., vol. 1, no. 1, pp. 1-14, 2016.

[7] S. Anjan, R. Aldouri, S. Nazarian, and J. Si, "Accelerated assessment of quality of compacted geomaterials with intelligent compaction technology," Constr. Build. Mater., vol. 113, pp. 824-834, 2016.

[8] P. K. R. Vennapusa, D. J. White, and M. D. Morris, "Geostatistical Analysis for Spatially Referenced Roller-Integrated Compaction Measurements," J. Geotech. Geoenvironmental Eng., vol. 136, no. 6, pp. 813-822, 2010.

[9] M. F. Nawaz, G. Bourrié, and F. Trolard, "Soil compaction impact and modelling . A review," INRA, pp. 291-309, 2013.

[10] W. Hu, X. Shu, X. Jia, and B. Huang, "Automation in Construction Geostatistical analysis of intelligent compaction measurements for asphalt pavement compaction," Autom. Constr., vol. 89, no. April 2017, pp. 162-169, 2018.

[11] E. A. Laksana, "Analisis Data Geostatistika dengan Universal Kriging," Universitas Negeri Yogyakarta, 2010. 